\title{
Preble's Blockade of the Barbary Coast
}

\section{Frederick C. Leiner}

\begin{abstract}
En novembre 1803, le Commodore Edward Preble de la marine américaine a déclaré un blocus de Tripoli, le troisième sur cette ville, dans la troisième année d'une guerre; les autres avaient été des échecs. Aucun compte des guerres de Barbarie n'a examiné les aspects juridiques de ce blocus. Cependant, une conformité américaine avec le droit international était essentielle, à la fois sur le plan diplomatique et aussi pour permettre une détermination judiciaire qu'un navire capturé en essayant de forcer le blocus était une "bonne prise.» Cet essai se penche sur le blocus de Preble à travers le prisme de la loi des nations qui a contraint et influencé les opérations navales
\end{abstract}

There are many accounts of the U.S. Navy's operations in the Mediterranean in the first years of the Nineteenth Century. ${ }^{1}$ The so-called "First Barbary War" (1801-05) was critical for the development of the navy as an institution, and for the careers of many of the service's most storied officers. ${ }^{2}$ The war lasted for more than four years. The war was punctuated by epic disasters and exhilarating triumphs: the grounding of the frigate Philadelphia and the imprisoning of her 307 officers and men for sixteen months; the expeditionary force of mercenaries, Arabs, and eight U.S. marines who captured Derna ("to the shores of Tripoli," as the Marine Corps anthem recites); and the raid that destroyed the captured Philadelphia in Tripoli harbor in February 1804. Few accounts of the war have more than scattered references to the U.S. Navy's blockade of Tripoli, and none examines the legal issues relating to the blockade or the legal problems associated

1 There is a vast literature on the naval operations against the Barbary corsairs. Among the popular accounts are Gardner W. Allen, Our Navy and the Barbary Corsairs (Boston, 1905); Glenn Tucker, Dawn like Thunder: The Barbary Wars and the Birth of the U.S. Navy (Indianapolis, IN, 1963); A.B.C. Whipple, To the Shores of Tripoli: The Birth of the U.S. Navy and Marines (New York, 1991); and Joseph Wheelan, Jefferson's War: America's First War on Terror 1801-1805 (New York, 2003).

2 Modern biographies of the major naval officers include Christopher McKee, Edward Preble: A Naval Biography, 1761-1807 (Annapolis, MD, 1972); David F. Long, Ready to Hazard: A Biography of Commodore William Bainbridge, 1774-1833 (Hanover, NH, 1981); Linda M. Maloney, The Captain from Connecticut: The Life and Naval Times of Isaac Hull (Boston, 1986); and Spencer C. Tucker, Stephen Decatur: A Life Most Bold and Daring (Annapolis, MD, 2004).

The Northern Mariner/Le marin du nord XXV, No. 2 (April 2015), 117-132 
with stopping, searching, and making prizes of vessels trying to run the blockade. ${ }^{3}$ This essay examines the initiation of the third U.S. naval blockade of Tripoli, at the end of 1803, under the third squadron commander in three years, Commodore Edward Preble. The essay looks at the institution of the blockade - as contemporaries did - through the prism of the law of nations ("international law" in the present day), and how the law constrained and influenced the blockade. Although ignored in the historiography, the law of blockade and the law of prize effected how naval officers of the early American republic approached their duties, and how they operated a blockade.

The Tripolitan War began in the spring of 1801, when the bashaw of Tripoli ordered his janissaries to cut down the flagpole outside of the U.S. consul's house, a symbolic and effective method of communicating the cutting of diplomatic ties and the onset of war. ${ }^{4}$ The United States, under the new presidential Administration of Thomas Jefferson, dispatched a series of naval squadrons to the Mediterranean in response, the first under Commodore Richard Dale in 1801, and the second under Commodore Richard V. Morris a year later. ${ }^{5}$ Dale tried to establish a blockade of Tripoli, and the U.S. consul to Tunis, William Eaton, announced the blockade in a circular letter to the European capitals on 23 July $1801 .{ }^{6}$ But Dale interpreted his orders as not allowing direct offensive operations against Tripoli, and with uncertain logistical support and potential threats from the other Barbary regencies, the blockade was brief and ineffective. ${ }^{7}$ When Dale's flagship, the frigate President, had to depart Tripolitan waters, the blockade became nominal, "enforced" by American diplomats who refused to issue safe conduct passports to shipping; not surprisingly, the blockade was, in the phrase of one historian, "not

3 Two contemporary American works on prize law, neither of which refers to prizes made in the Barbary Wars, are Henry Wheaton, A Digest of the Law of Maritime Captures and Prizes (New York, 1815), and Joseph Story, a Supreme Court Justice, who anonymously wrote in the official volumes of the Supreme Court reporter ("U.S."), "On the Practice in Prize Causes," 14 U.S. (1 Wheaton) 494-506 (1816) and "Additional Notes on the Principles and Practice in Prize Causes," 15 U.S. (2 Wheaton), Appendix, Note 1, 1-80 (1817). Two modern works on prize law are Donald A. Petrie, The Prize Game: Lawful Looting on the High Seas in the Days of Fighting Sail (Annapolis, MD, 1999), and Richard Hill, The Prizes of War: The Naval Prize System in the Napoleonic Wars, 1793-1815 (Stroud, Gloucestershire, England, 1998).

$4 \quad$ Allen, Our Navy and the Barbary Corsairs, 91.

5 Whipple, To the Shores of Tripoli, 63-66.

6 Dudley W. Knox, ed., Naval Documents Related to the United States Wars with the Barbary Powers ["NDBW"], 7 vols. (Washington, 1939-45), 1:528, Circular Letter to U.S. Agents and Consuls in Europe, 23 July 1801.

7 Allen, Our Navy and the Barbary Corsairs, 97, notes that Dale interpreted his orders correctly - as not allowing the squadron to take prizes, which meant that the most the blockading warships could do was to stop and try to detour neutral merchant ships from Tripoli. McKee, Edward Preble, 91, notes that Dale's squadron blockaded Tripoli from July until early September 1801, "when a shortage of provisions and a sudden increase in the sick list forced Dale to raise the blockade and run down to Gibraltar." 


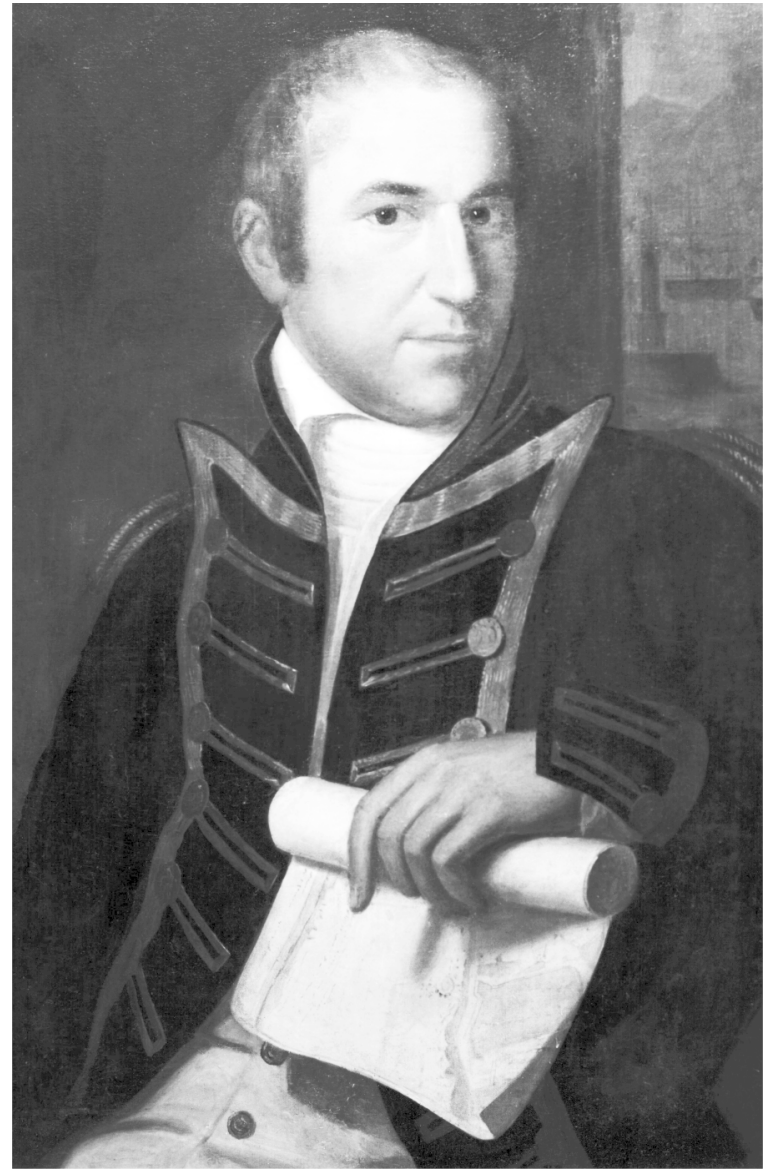

Commodore Edward Preble, detail from the painting, circa 1805, by Rembrandt Peale. tight." " Commodore Morris directed and maintained his blockade in 180203 so ineptly that he was censured by a naval court of inquiry and dismissed from the service. ${ }^{9}$ What is remembered from those early American naval campaigns is a single battle won by the schooner Enterprise over a Tripolitan brig in August 1801. ${ }^{10}$ But keen observers recognized that isolated naval battles were not the key to forcing the bashaw to terms. Rather, as one U.S. diplomat stationed in Barbary wrote to another U.S. diplomat, "a close blockade and now \& then other galling and distressing enterprizes must convince the Government of Tripoli, that it is peace, that is wanted." 11

From the captain's cabin on board the frigate Constitution, at anchor in Gibraltar Bay, on 12 November 1803, Commodore Edward Preble again declared Tripoli under blockade. Preble, a Maine native, had served in the Massachusetts state navy in the

8 Tucker, Dawn Like Thunder, 148-49.

9 In the opinion of the court of inquiry into Commodore Morris' "inactive and dilatory conduct," several grounds of censure related to his failure to press the blockade of Tripoli, including "[i]n raising the blockade of Tripoli on the 26th June 1803[,] and carrying the whole squadron from thence to Malta, Messina, Naples, Leghorn, \&c. without necessity or any adequate object, and never afterwards sending any part of the squadron to the coast of Tripoli." $N D B W, 4: 38-39$, Report of the Court of Inquiry into Commodore Richard V. Morris, 13 April 1804. See Tucker, Dawn Like Thunder, 159-60, 171-86; Whipple, To the Shores of Tripoli, 86-89, 95-101; Wheelan, Jefferson's War, 153-57.

10 On 1 August 1801, under the command of Lt. Andrew Sterett, the schooner Enterprise defeated the 14-gun Tripoli. After the Tripoli twice feigned surrender, the Enterprise pummelled her into submission, inflicting 60 casualties, while no one was hurt on the Enterprise. After dumping her cannon, anchors, and rigging overboard, and cutting down her masts, Sterrett allowed the Tripoli to limp home under a jury rig. See Tucker, Dawn Like Thunder, 142-44; Whipple, To the Shores of Tripoli, 79-80; Wheelan, Jefferson's War, 118-19. NDBW, 4:59-61, Richard O'Brien to Tobias Lear, 24 April 1804. 
Revolutionary War, and then sailed for fifteen years as a merchant shipmaster. Commissioned into the navy as a lieutenant in 1798, he was promoted to captain in 1799 and given commend of the frigate Essex, which he sailed to the East Indies to protect American merchantmen against French privateers in the Quasi-War. Made commander of the third squadron sent to the Mediterranean, he had sailed from Boston in the frigate Constitution in August 1803. ${ }^{12}$ When Preble proclaimed the blockade in November 1803, the Mediterranean squadron consisted of his own ship, the Constitution, rated at 44 guns; the 16-gun brigs-of-war Siren and Argus; and the schooners Enterprize, Vixen, and Nautilus, with 12 guns each. ${ }^{13}$ Ironically, when he proclaimed the blockade, Preble did not yet know that, on 31 October 1803, the other American frigate in the squadron, the 36-gun Philadelphia, had run aground off Tripoli, her officers and crew had been taken prisoner, and after getting the Philadelphia off the rocks, the Tripolitans had brought her into the port of Tripoli. ${ }^{14}$

To be lawful under the law of nations, a blockade had to be announced in advance so that the governments of neutral countries, whose merchants otherwise might freely and lawfully trade with the blockaded ports, could advise their merchants and ship owners. ${ }^{15}$ Moreover, for a blockade to be lawful, it had to be "effective," in other words,

12 Dyspeptic, and known as a strict disciplinarian, Edward Preble (1761-1807) had exacting standards. Many of the navy's future captains served under him, inculcated his methods, and came to venerate him. Christopher McKee, Edward Preble: A Naval Biography, 1761-1807 (Annapolis, MD, 1972)

13 As to the details for each ship, see NDBW, 7:68 (Argus), 7:70 (Constitution), 7:71 (Enterprize); 7:75 (Nautilus), 7:77-78 (Siren), and 7:80 (Vixen).

14 The news of the loss of the Philadelphia came slowly to Preble. On 24 November 1803, the British frigate Amazon hailed Preble's flagship, the Constitution, southwest of Sardinia. The British captain passed along "the melancholy and distressing Intelligence" to Preble. NDBW, 3:175, extract from diary of Captain Edward Preble, 24 Nov. 1803. Preble specified how he learned the news in a letter to the Secretary of the Navy. Ibid., 3:256, Edward Preble to Robert Smith, 10 Dec. 1803.

15 In The Vrouw Judith, 1 Rob. 150, 152 (1798), Sir William Scott, the judge of the British High Court of Admiralty, wrote, "It is certainly necessary that a blockade be intimated to neutral merchants in some way or other. It may be notified in a public and solemn manner, by declaration to foreign governments; and this mode would always be most desirable, ... but it may commence de facto, by a blockading force giving notice on the spot to those who come from a distance ... Vessels going there are, in that case, entitled to notice before they can be justly liable to the consequences of breaking a blockade." The "Rob." citation refers to Christopher Robinson, who began to publish editions of the British admiralty decisions in 1801 as Reports of Cases Argued and Determined in the High Court of Admiralty $4^{\text {th }}$ ed., 6 vols. (London, 1812). As to the contemporary importance and dissemination of Robinson's publication of admiralty cases, see John D. Gordan, III, "Publishing Robinson's Reports Of Cases Argued And Determined In The High Court Of Admiralty," Law and History Review XXII (Aug. 2014), 525-73. As to the international renown of Scott on prize law, Wheaton called him "that great man" in the preface of his treatise, noting that "the decisions of Sir William Scott merit the highest consideration, on account of their intrinsic value and the judicial eloquence by which they are adorned." Wheaton, Digest of the Law of Maritime Captures, vi. 
enforced by warships on station that could intercept vessels attempting to enter the port after notice of the blockade had been given. ${ }^{16}$ Blockades that were proclaimed but that were not supported by adequate power on the scene were said to be "paper" blockades. ${ }^{17}$

Paper blockades were no mere abstract legalism to the United States, and had been a constant diplomatic problem for the young American republic. The United States had remained neutral in the French Revolutionary Wars that had embroiled Europe for a decade (1793-1802) - and the American economy soared - as American merchant ships carried grain and commercial goods to wartime Europe. ${ }^{18}$ Britain's Royal Navy had asserted blockades over the ports and coastline of France and her allies, including Spain, even when there were no ships standing off a given port. These paper blockades had vexed American merchants and diplomats, and led to steep losses when American merchant ships sailed towards a port, or out of it, and were captured by a patrolling British warship. During the Adams Administration, the then-secretary of state, John Marshall, had condemned paper blockades, writing that "[i]f the effectiveness of the blockade be dispensed with [as a legal prerequisite], then every port of all belligerent powers may, at all times, be declared in that state, and the commerce of neutrals be thereby subjected to universal capture ... It is therefore of the last importance to neutrals, that this principle be maintained unimpaired." ${ }^{19}$ The change in Administrations when Thomas Jefferson became president in March 1801 did not affect the United States' view. Responding to a purported Spanish blockade of Gibraltar purportedly made effective by Spanish gunboats across the bay at Algeciras, which were moored, Secretary of State James Madison wrote that "[i]f, because a neutral vessel bound to Gibraltar can be annoyed and put in danger by waylaying cruisers, which neither occupy the entrance to the harbor, nor dare approach it, and by reason of that danger is liable to capture, every part of the Mediterranean coasts and islands ... may with equal reason be proclaimed in a

16 "[A] blockade must be 'declared as an act of state, must be effective over the whole of the declared area and must be continuous." Hill, Prizes of War, 11. In The Betsey, 1Rob. 93 (1798), Sir William Scott wrote that for a prize to be valid for violating a blockade, three things must be proved: (1) the existence of an actual blockade; (2) the captured ship knew that that the blockade had been established; and (3) the captured ship had committed some act of violation, either by going in or coming out with a cargo laden after the commencement of the blockade.

17 "[A] declaration of [a] blockade which is not supported by the fact [of ships stationed off the port] cannot be deemed legally to exist." Wheaton, Digest of the Law of Maritime Captures, 193. In The Frederick Molke, 1 Rob. 86 (1798), Sir William Scott wrote that "Nothing further is necessary to constitute blockade, than there should be a force stationed to prevent communication, and a due notice, or prohibition, given to the party." Petrie, The Prize Game, 107-08, distills five rules for a legal blockade.

18 Douglass North, The Economic Growth of the United States 1790-1860 (1961; repr., New York, 1966), 46, summarizes that "[b]etween 1793 and 1808, the economic development of the United States was tied to international trade and shipping."

19 Letter, John Marshall to Rufus King, 20 Sept. 1800, in Charles T. Cullen, ed., The Papers of John Marshall (Chapel Hill, NC, 1984), 4:292. The letter is also printed in American State Papers, 1789-1838, 38 vols. (ASP), class one: Foreign Relations (Washington, 1834), 2:486-90. 
state of blockade, and the neutral vessels bound thereto made equally liable to capture." The "monstrous" consequences of such a principle demonstrated to Madison the invalidity of a paper blockade. ${ }^{20}$ On 24 October 1803, only three weeks before Preble proclaimed the blockade of Tripoli, the British navy announced a blockade of San Domingo. The United States formally protested the British blockade of San Domingo because there was no real force to make it effective. Madison wrote Anthony Merry, the British minister to the United States, that "[h]ere is another and still more extraordinary instance in which a blockade is pretended and declared by a few Ships against a whole Island, of vast extent and abounding with ports and places of commerce." Madison asked Merry to press the matter with his government, to "remove without delay, a source of so much injury and irritation." 21

Preble announced his blockade of Tripoli in letters to the United States ministers in London, Madrid, and Paris. In a single sentence of dangling phrases, he noted that "[w]hereas the United States of America and the Regency of Tripoli, are in a state of War and actual hostility with each other I have thought proper in order to distress the Enemy by preventing any supplies from reaching him to Blockade the Port of Tripoli by a detachment of Ships of War, acting under my orders." Preble asked each American minister to inform his host government, as well as the consuls of neutral countries, of the blockade, so that they might "warn the vessels of their respective Flags, that all Neutral Vessels that attempt to enter the Port of Tripoli, or are met with on the coast near that Port after this notice is received by such Neutral Powers, will be stopped by the Squadron under my command and sent into port for adjudication." Preble sent the same letter to the U.S. consuls at the major Mediterranean ports - Marseilles, Barcelona, Cadiz, Alicante, Malaga, Livorno, Naples, Lisbon, Gibraltar, and Tangier. ${ }^{22}$ He mentioned his proclamation of the blockade almost as an afterthought in a letter to the U.S.consul in

20 ASP, Foreign Relations, 2:476-78, James Madison to Charles Pinckney, 25 Oct. 1801.

$21 N D B W, 3: 290-91$, James Madison to Anthony Merry, 24 Dec. 1803. The difference between the United States and Britain over paper blockades demonstrates that maritime law was not monolithic. By the early Nineteenth Century, the legal regime at sea, derived initially from the rolls of Oléron of the 12th century and centuries of treaties and customs among the European sovereigns, was an established body of law. Indeed, courts applying maritime law sometimes applied the decisions of other nations' admiralty courts, and sought to meld their own decisions to the framework of that law, as the Americans' respect for Sir William Scott's opinions shows. Nonetheless, each country's courts had national characteristics, and acted consistent with national strategic requirements, sometimes (as in the case of the High Court of Admiralty) at the command of the government.

$22 N D B W, 3: 215-16$, Circular Letter, Edward Preble to James Monroe, 12 Nov. 1803. Upon receiving Preble's letter, the American consul at Lisbon notified nine European consuls there that Preble had issued orders "for a detachment of [his] Squadron to Blockade the Port of Tripoli \& when invested, that all Vessels attempting to enter or depart from said place, will be treated according to the Law of Nations established in such cases." Ibid., 3:308, William Jarvis to James Gambier, 2 Jan. 1804. Similarly, the U.S. consul at Tunis wrote Preble that he had "officially communicated to the Government of Tunis, as well as to the Consuls of Neutral Powers resident here, the Blockade of Tripol[i]." Ibid., 3:359, George Davis to Edward Preble, 26 Jan. 1804. 
Malta. ${ }^{23}$ Because the United States had no diplomatic representation with the Ottoman Empire, Preble sent the proclamation of the blockade to the Sultan through the French ambassador in Constantinople, General Brune. Preble wrote that "our object in Blockading that port [Tripoli], is to distress an Enemy who has made War on the commerce of the United States of America without any cause except those founded on avarice and injustice." The blockade was, in Preble's view, "of the first importance in compelling them to a peace that may be consist[e]nt with the honor and dignity of our Country." 24

The step had enormous legal and strategic effects. Legally, it meant that as soon as it appeared that a neutral merchant ship was approaching, and steering for, Tripoli, in an attempt to break the blockade, American warships could lawfully stop the merchant ship for inspection. Customarily, a warship stopped a merchant vessel by firing a gun ahead or over her, a show of force that compelled the merchant vessel to "heave to." ${ }^{25}$ If the blockade-running ship refused to heave to or used force to resist, a blockading vessel could lawfully fire into her. ${ }^{26}$ Once stopped for inspection, if the papers of the neutral merchant vessel revealed that her cargo was destined for or consigned to the merchants of the belligerent port, and that her owners or captain knew or should have known of the proclamation of blockade, then the ship with her cargo could be seized as in violation of the embargo. As the only American treatise on the law of nations existing at the time phrased it, "if a neutral vessel were to be stopped by a belligerent, in the act of proceeding into a port effectively blocked up, after due notice of its being in that predicament; confiscation would be [the] lawful penalty." ${ }^{27}$ Customarily, the seized ship (the "prize") was placed under the command of a midshipman or junior lieutenant, designated the "prize master," who with a handful of seamen sailed the prize ship into a port of the capturing nation, with all her papers, the cargo untouched, and a master or

$23 N D B W, 3: 261$, Edward Preble to Joseph Pulis, 10 Dec. 1803. Preble wrote in the last paragraph of his letter, "I shall sail from this place [Syracuse, Sicily] tomorrow for the Coast of Tripoli where I have now some vessels cruizing - You will perceive by the enclosed that Tripoli is at present and will continue to be in a state of blockade."

$24 N D B W, 3: 469$, Edward Preble to General Guillaume-Marie-Anne Brune, 4 March 1804.

25 One contemporary treatise described the inspection process as follows: "This proceeding is commenced by giving a signal to approach with a speaking-trumpet, or by firing a cannon loaded with powder only; a boat is then sent to reconnoitre, and to examine the papers with which the vessel is furnished for the voyage: these documents ought to show, in the most convincing manner, to what nation the vessel belongs, the nature of the goods which compose the cargo, and who are the owners." D.A. Azuni, The Maritime Law of Europe, trans. William Johnson (New York, 1806), 2:202.

26 "In opposing, by flight, or force, the search which a belligerent has a right to make, [the master of a neutral vessel] manifests an hostile intention, or gives just reasons to suspect a real enemy, or at least one who carries with him effects belonging to enemies, or goods [that are] contraband of war. The law of nations justifies the use of force against any one who opposes the perfect right of another [to stop and search]." Azuni, Maritime Law of Europe, 2:211.

27 William Barton, A Dissertation on the Freedom of Navigation and Maritime Commerce ... as are Founded on the Law of Nations (Philadelphia, 1802), 213. 
mate of the prize ship to give testimony, if necessary. If the admiralty court reviewing the capture affirmed its validity (declared "good prize"), the ship or her cargo, or both, would be condemned and sold at public auction, the proceeds divided by statute amongst the officers and crew of the capturing ship. ${ }^{28}$

Of course, this procedure was somewhat problematic for the United States Navy operating in the Mediterranean, thousands of miles away from the nearest American port, and thousands of miles from a U.S. court that was empowered to rule on a prize. Yet the legal principle requiring a prize ship or prize cargo to be adjudicated by a court of the captor's own country - or at least the court of a co-belligerent nation - was emphasized in two ways. First, the law of nations mandated that only the courts of the capturing country, or those of a co-belligerent, had jurisdiction over the prize. ${ }^{29}$ Second, if the court of a country that was not at war purportedly condemned a captured ship as "good prize," or allowed its territory to be used for a prize proceeding, the law of nations refused to regard the condemnation as legitimate, and the captor did not receive clear title to the prize. $^{30}$ If a prize had not been legitimately condemned by a proper court, the captors could try to sell the vessel or cargo, but without clear title, the prize was like "fenced" property, and at least theoretically, could later be judicially arrested and restored to its proper owners. $^{31}$ In the American Revolutionary War, before France declared war against Britain, American warships could not use the then-neutral courts of France nor Benjamin Franklin, the American minister, to condemn British prizes, and had to sell them furtively to French buyers, with the price discounted for the lack of good title. ${ }^{32}$

28 See, e.g., Petrie, The Prize Game, 147-63, for the rules relating to prize-taking, including the process of stopping, searching, and bringing prizes into port for judicial proceedings.

29 "The validity of maritime captures is ... determined in courts of prize established in the country of the captor." Wheaton, Digest of the Law of Maritime Captures, 258. "Nor can the courts of a neutral country decide on the question of prize as between the belligerents." Azuni, Maritime Law of Europe, 2:262n by translator.

30 In The Flad Oyen, 1 Rob. 135, 139 (1799), the British High Court of Admiralty held that a captured English ship taken into Bergen, Norway, and condemned as good prize by the French consul there, was not legally condemned. Sir William Scott was outraged at the idea that a French consul in a neutral country (Norway was then in a union with Denmark, and at the time neutral in the French Revolutionary Wars) could act as a prize judge. "[F]or the very first time in the world," Scott wrote, "an attempt is made to impose upon the Court a sentence of a tribunal not existing in the belligerent country, but of a person pretending to be authorized within the dominions of a neutral country." Scott found the French consul's proceeding "inadmissible." Ibid., 141 and 141 na. See also Azuni, Maritime Law of Europe, $2: 262 \mathrm{n}$, " $\ldots$ it appears to be a well established principle, that a belligerent nation cannot institute a prize-court in a neutral country."

31 Petrie, The Prize Game, 144-45, demonstrates the importance of judicial condemnation in passing title in a prize vessel or goods to a later owner, using the modern analogy of a car sale with the title papers filed in the department of motor vehicles.

32 See Tim McGrath, Give Me a Fast Ship: The Continental Navy and America's Revolution at Sea (New York, 2014), 123; Michael J. Crawford, "The Hawke and the Dove, a Cautionary Tale: Neutral Ports and Prizes of War During the American Revolution," The Northern Mariner/Le marin du nord XVIII (July/Oct. 2008), 49-66. 
These principles had been brought home to Americans in the 1790s, when Revolutionary France was at war with most of Europe, and French privateers in the western Atlantic and Caribbean seized prizes and brought them into (neutral) United States ports for condemnation by French consuls, until the Supreme Court put a stop to it in $1794 .{ }^{33}$ In the recently concluded 1798-1800 Quasi-War against France, American warships sailed their French prizes hundreds of miles across the open ocean from the Caribbean to Boston or other ports, to bring them into admiralty courts for prize proceedings. ${ }^{34}$ Now, in another naval war even further from America, United States naval officers could not use British, French, or Spanish courts, however close at hand in the Mediterranean, to condemn prizes of Tripolitan ships, because those countries were not at war with Tripoli. In January 1803, after the Enterprize had captured a polacre called the Paulina off Malta, the British governors of both Malta and Gibraltar informed Commodore Morris that the vice-admiralty courts at each port would not be open to hear American prize cases. ${ }^{35}$

Strategically, the proclamation of a blockade meant that Preble was committing the United States Navy to maintain a close and constant blockade of an enemy port with the few ships available to him from his squadron, based on the logistical support from the British at Malta and from the Kingdom of Naples at the Sicilian port of Syracuse. This was an audacious move. To maintain warships on station, in all seas and in all seasons, was a logistical challenge, requiring Preble to rotate his small warships on blockade duty into port for maintenance, replenishment, and repair. Preble himself expressed doubts. In December 1803, he wrote Secretary of the Navy Robert Smith, "We sail tomorrow for the coast of Tripol[i], and are well prepared for a Winter's Cruise. I shall remain off the coast, as long as it is possible for any of their cruisers to keep out; but I do not think it will be possible to cruise all Winter without hazarding too much; for should any accident

33 In Glass v. The Sloop Betsey, 3 U.S. (3 Dall.) 6 (1794), the Supreme Court held that U.S. district courts had exclusive jurisdiction over prize cases brought into American ports, and that no foreign power could institute a court within the jurisdiction of the United States without express permission. The French argued that the 1778 treaty of alliance authorized their consuls in America to judge prize cases, and that U.S. courts lacked jurisdiction because they were not the courts of the captors, an argument which had prevailed in the lower courts throughout the country. See William R. Casto, Foreign Affairs and the Constitution in the Age of Fighting Sail (Columbia, SC, 2006).

34 See, e.g., Frederick C. Leiner, "The Seizure of the Flying Fish," American Neptune LVI (spring 1996), 131-43. At the time the United States fought the Quasi-War, Britain was also fighting the French. Because Britain was a co-belligerent, under the law of nations, British vice-admiralty courts at Jamaica and Antigua could have ruled on American prizes, if U.S. naval commanders had been authorized to sail their prizes into those British colonies. Paradoxically, the U.S. government authorized American privateers (but not warships) to send their prizes into the ports of "the British dominions, or those of any other Power in friendship with the United States, but at war with France," if the laws of those places allowed their vice-admiralty courts to libel and condemn prizes taken by another co-belligerent. ASP, Foreign Relations, 2:365-66, "Instructions for the Private Armed Vessels of the United States" [undated but July 1798]. 
happen to this ship, and any of the other Barbary Powers should break out upon us, the Consequences may be dreadful to our commerce in these Seas." "36 Without the Philadelphia, Preble needed more ships, and asked the secretary to "send me another Frigate or two, and a Frigate to relieve the Argus at Gibraltar, so that I can have the services of that Brig, [with which] I will so compleatly Blockade Tripol[i] and annoy the Coast, as to lessen the Bashaw's demands ... and perhaps oblige him to sue for peace." 37 Indeed, as of December 1803, the U.S. Navy had no ships off Tripoli enforcing the supposed new blockade. ${ }^{38}$

The French foreign minister, Charles Maurice Talleyrand-Perigord, probed the legality of the American blockade on that very point - that the United States had instituted a paper blockade. ${ }^{39}$ In response to the publication of the blockade, Talleyrand wrote the U.S. minister in Paris, Robert Livingston, asking him to force Preble to back down. Talleyrand complained that Preble had "stretched the application of these rights [to blockade] in a manner which tends to injure neutral commerce without being justified by the rules generally adopted in the maritime neutrality conventions." Talleyrand observed that under the law of nations, the designation of a port under blockade "should apply only to a port that is attacked by a number of vessels proportional to the force of the place, and which are near enough that there is an obvious danger that the port will be entered." Talleyrand noted that the United States only had a "single frigate cruise off Tripoli" (Talleyrand meant the Philadelphia, not yet knowing she had been captured) which clearly did not suffice as a basis to declare not only Tripoli, but also the adjacent Tripolitan coast, under blockade. The wily Talleyrand knew just how to bring the point home to Americans: extending a blockade to the coast was not only beyond what the law of nations had recognized, he wrote, but also would lend support to the British, who had

$36 N D B W, 3: 256-60$, Edward Preble to Robert Smith, 10 December 1803.

37 Ibid.

38 Of Preble's six-ship squadron, the frigate Constitution and schooner Enterprize were about to sail for Tripoli; the schooner Nautilus was convoying a storeship and would then cruise off Cape Bon, northeast of Tunis; the schooner Vixen had sailed to Gibraltar with dispatches; the brig Syren had sailed from Gibraltar to Livorno, to pick up tribute to deliver to Algiers; and the brig Argus had sailed to Marseilles and Livorno with a convoy, and she then would return to Gibraltar to deter Morocco, and occasionally cruise off southern Spain. Ibid.

39 Talleyrand (1754-1838) was born into an aristocratic Parisian family. Because of a foot deformed in a childhood accident, Talleyrand could not consider an army career, and entered the priesthood. Appointed the bishop of Autun in 1789, at the beginning of the French Revolution, Talleyrand served as a clerical member of the Estates-General, where he advocated the expropriation of Church property. At various times, he served as foreign minister under the French Directory, Consulate, Empire, and Restoration, where he was legendary for his aloof personality, refined manners, shrewdness, and venality. In 1798, the $\mathrm{XYZ}$ affair began with Talleyrand's demand through intermediaries for bribes as quid pro $q u o$ for the American diplomats to meet French emissaries; the refusal of John Marshall, Elbridge Gerry, and Charles Cotesworth Pinckney to pay despite enormous pressure and threats, led to the Quasi-War. The classic biography in English is Duff Cooper, Talleyrand (London, 1932). 
set the example by extending a blockade to the entire coastline of France, even where the Royal Navy had no constant presence. Britain had, in Talleyrand's view, violated international law, and he pointedly observed, "No nation has been disposed to imitate it, nor has been interested in doing so, and perhaps the United States is more interested than any other power in not adopting a system contrary to the rights and commerce of neutrals." In sum, Talleyrand wrote that he was "[c]onvinced that Commodore Preble cannot have been authorized to ignore principles which have become, in this matter, the basis of international law and universally accepted usage." He asked Livingston to direct Preble to institute a blockade only as the law allowed, of the port of Tripoli only, and only when "all the indispensable conditions are fulfilled," i.e., the American squadron mounted sufficient power to enforce the blockade. ${ }^{40}$

In Washington, the Jefferson Administration privately recognized that Preble had instituted a blockade that the United States itself would not have recognized. Secretary of State James Madison wrote James Monroe, the U.S. minister to the Court of St. James's, that Preble proclaimed a blockade "on the grounds and in the form of the British proclamations, used in cases where [the United States contended] no effective blockade had taken place." Madison informed Monroe that if the British brought up the inconsistency in the American position, Monroe was to counter that Preble had issued the blockade proclamation with "no instruction" from the Administration, and that "instructions since transmitted [to] him will set and keep him right on that subject." 41

Setting and keeping Preble right on that subject was the responsibility of his civilian superior, Secretary of the Navy Smith. ${ }^{42}$ Smith responded to the notification of the blockade of Tripoli with a February 1804 letter to Preble, written at the specific direction of President Jefferson. In an era before the telegraph, radio, or computer, Smith realized that his response would not arrive in the Mediterranean for many weeks. Knowing Preble as he did, Smith could not have been concerned that Preble intended to mount only a paper blockade of Tripoli, and he knew Preble would make the blockade "effective" with sufficient ships long before he would receive Smith's letter. Using double negatives (language suggesting President Jefferson's direct authorship), Smith

$40 \quad N D B W, 3: 372$, Charles Maurice Talleyrand to Robert Livingston, 30 January 1804.

$41 \quad N D B W, 3: 472-73$, James Madison to James Monroe, 5 March 1804.

42 A Princeton graduate, Robert Smith (1757-1842) had been a leading admiralty lawyer in Baltimore, representing the claimants in the district court in Glass v. The Sloop Betsey. See note 33, above. President Jefferson appointed him secretary of the navy in 1801 on the suggestion of Smith's brother, Representative (later Senator) Samuel Smith. Robert Smith served as navy secretary (1801-1809) and, under Madison, as secretary of state (1809-1811), until forced to resign based on policy disagreements and the intense hostility of the Smiths to Albert Gallatin. Smith ran the Department of the Navy in an Administration that was indifferent about, and sometimes hostile to, the very notion of a navy. Smith was an industrious, capable, courteous man, and without adequate funds, was able as secretary of the navy to maintain a squadron fighting thousands of miles away, and to establish the navy on professional lines. There is no biography, but he is described in Christopher McKee, $A$ Gentlemanly and Honorable Profession: The Creation of the U.S. Naval Officer Corps, 1794-1815 (Annapolis, MD, 1991), 7-9, 11. 
wrote that the basic principle of a blockade was that "the trade of a neutral nation in articles, not contraband, cannot be rightfully obstructed to any port not actually blockaded by a force so disposed before it as to create an evident danger of entering it." ${ }^{43}$ Once Preble had the force available, the navy would "have a right to prevent any vessel from entering it and to capture for adjudication any vessel that shall attempt to enter the same with a knowledge of the existence of the blockade." But the navy secretary wrote that Preble surely was "sensible" that because of America's own economic interests, as well as its "disposition," U.S. policy was to support the rights of neutral nations, and as the commander of the American naval squadron in the Mediterranean, he was to "avoid whatever may appear to you to be incompatible with those rights." Smith cautioned Preble specifically "not [to] take as prize any vessel attempting to enter the Port of Tripoli without such knowledge [of the existence of the blockade]." If the master of a neutral vessel attempting to enter legitimately was "without a previous knowledge of the existence of the blockade, you will give the commanding Officer of such vessel notice of such blockade and forewarn him from entering," but, of course, if he tried again, "you will be justifiable in sending her into port for adjudication." Thus, the Administration enjoined Preble not to consider his circular communication to the European countries as conclusive evidence that every person attempting to enter had previous knowledge of the blockade. $^{44}$

Significantly, the British, accused by both the French and the Americans of sponsoring paper blockades, raised no objection to Preble's announced blockade of Tripoli. The civil governor of Malta, Sir Alexander Ball ${ }^{45}$ wrote Preble that having been notified by the American consul that Preble had declared the port of Tripoli under blockade, he would "discourage" merchants sending goods there, and "hereafter [would be] prohibited as much as possible by this Government." Ball merely informed Preble

43 The use of double negatives in the letter confuses the exact meaning, and might seem like an instruction to limit the blockade of Tripoli to contraband goods found on neutral vessels. This was not the case, as Smith's letter went on to state, and as borne out by Preble's practice.

$44 N D B W, 3: 389$, Letter, Robert Smith to Edward Preble, 4 Feb. 1804. The letter is also reprinted in ASP: Foreign Relations, 3:372. Preble responded that that the Administration "may rely with confidence that I shall conduct the blockade of Tripol[i] with discretion, and shall pay proper respect to the rights of Neutrality agreeable to the wishes of the President." $N D B W, 4: 40-44$, Edward Preble to Robert Smith, 19 April 1804. Interestingly enough, Smith's letter to the captain who succeeded Preble as the squadron commander defined the blockade in identical language as the letter Smith had written Preble. Ibid., 4:133, Robert Smith to Samuel Barron, 31 May 1804.

45 Sir Alexander Ball (1757-1809), captain of a British ship-of-the-line at the Battle of Nile in 1798, was one of Nelson's "band of brothers." In 1804, Ball, then a rear admiral, was the civil governor of Malta. He was a reflective man, courteous, with sound judgment. From May 1804 to October 1805, Samuel Taylor Coleridge served as Ball's secretary. See Ludovic Kennedy, Nelson and His Captains (1951; repr. London, 1975), 109-12, 162-63, 338; Brian Lavery, Nelson and the Nile: The Naval War Against Bonaparte 1798 (Annapolis, MD, 1998). 
that Maltese merchants had already purchased 1000 bullocks in Tripoli to feed the British army garrison, but the cattle had not yet been shipped, and he asked the American commodore to allow the freight to proceed through the embargo. ${ }^{46}$ The British military commander at Malta, Major General W.A. Villetts, then wrote Preble that the bullocks would sail on two Maltese vessels, La Vergine del Carmine and Il Santissimo Crocifesso, with Maltese crews, and he asked Preble to allow them "to pass without hindrance or molestation." ${ }^{, 47}$ Preble agreed to let the two ships to pass through the blockade, providing that they sailed to Tripoli in ballast, and he signed and sent two passports to Villetts for the vessels. ${ }^{48}$ Under the law of nations, neutral ships already in a belligerent port and loaded for sea when a blockade was declared were allowed to leave with their cargoes; for Preble to allow neutral (British) ships to enter empty (in ballast) and leave with a cargo purchased before the blockade was a slight extension of that principle. ${ }^{49}$ Then, too, the American naval squadron relied on Malta as its principal base for naval operations against Tripoli, and it made sense for Preble not to alienate his host. Yet Preble explained his agreement in terms of the lack of effectiveness of his blockade, writing home, "I hope you will approve of this indulgence, as the season of the year is such, that it is not prudent to keep so near the Coast as to enable us closely to Blockade it. After February has expired I shall be able to cruise near the Coast, and no further indulgence shall be granted to any Nation." 50

Besides the legal problems in establishing a blockade, the central concern was whether a blockade would work to degrade the Tripolitan defenses or economy, and make the bashaw, Tripoli's autocratic leader, want peace. William Bainbridge, the imprisoned captain of the Philadelphia, thought a blockade would be useless. Bainbridge wrote Preble:

$46 \quad N D B W, 3: 291$, Alexander Ball to Edward Preble, 24 Dec. 1803.

$47 \quad N D B W, 3: 328$, W.A. Villetts to Edward Preble, 13 Jan. 1804.

$48 N D B W, 3: 332-33$, Edward Preble to Alexander Ball, 16 Jan. 1804 and Edward Preble to W.A. Villetts, 16 Jan. 1804.

49 Wheaton, Digest of the Law of Maritime Captures, 201 ("A neutral ship departing [from a belligerent port], can only take away a cargo bona fide purchased and delivered before the commencement of the blockade").

$50 N D B W, 3: 337-40$, Edward Preble to Robert Smith, 17 Jan. 1804. Ironically, on 16 February 1804, the schooner Nautilus captured one of the Maltese brigs, Santissimo Crocifisso, standing in towards Tripoli, carrying a cargo of hemp, wine, scantling, and several bales of linen and merchandize. Because the Santissimo Crocifisso carried cargo for Tripoli, she was in violation of Preble's own passport. $N D B W, 3: 411$, Richard Somers to Edward Preble, 16 Feb. 1804 and 7 March 1804. Preble determined the brig carried "Plank and Nails for building Gun Boats [and] Building Stone for the Bashaw's New Forts," and sailors searching her had uncovered "a great number of letters for Tripol[i] were found secreted under the Transom ceiling and the Bashaw of Tripol[i]'s passport to the Tripolines found on board." Ball told Preble that he considered the captures as "perfectly legal, as he had given public Notice of the Blockade, and had forbid any communication with Tripol[i]." Ibid., 4:40-44, Edward Preble to Robert Smith, 19 April 1804. Ultimately, however, Preble worked out a deal in which he returned the vessel (but not her cargo) to the owners. See note 62. 
A blockade has, and ever will be found[,] a wrong system to pursue, with this Regency; it is only hazarding a great risque (as I have fatally experienced) without the least effect, except the Interest of a few Jewish Merchants. The Country abounds with plenty, and every superfluous supply can readily be got from Tunis by Land. The situation of their Harbour, and coast is such, that their small cruisers which are the most dangerous, can always go to Sea, and return into port in spite of the most vigilant cruisers stationed off here. ${ }^{51}$

Preble, however, brushed off Bainbridge's criticism. He wrote Tobias Lear, "I differ in opinion with [Bainbridge] respecting a Blockade. I think it will have a good effect." 52

Preble instructed his commanders how they were to enforce the blockade. To the commander of the schooner Vixen, Preble wrote that he should "capture all Tripoli[tan] or other Vessels on which Tripoli[tan] property is laden which you may happen to fall in with. You are not to suffer the vessels of any nation to enter or to have commerce with Tripol[i], but have a right to treat as an Enemy whoever may endeavor to enter that place or carry any thing to it whilst blockaded by us. You are to respect the rights of Nations with whom we are at Peace and not to capture Vessels within the Jurisdictional limits or under the protection of such nations." 53 While reiterating his orders to other commanders, he specified that they should "capture all Vessels belonging to the Bashaw of Tripol[i] or his Subjects and to Annoy and distress the Enemy by every means in your power." Preble directed that no vessels of any nation should be allowed "to enter, or to have Commerce with Tripol[i], and any Vessels who may endeavour to enter that place, whilst Blockaded by us, without permission from me for doing so, you are to detain and send into Malta for examination." Preble charged his captains with "strictly" examining any vessel stopped on suspicion of running the blockade "both with regard to papers and Crew; and suffer no Vessels to pass without first searching her between Decks." 54

In directing the movements of his small squadron, Preble tried to ensure that sufficient force would be available to blockade Tripoli. Although in the winter months of 1803-04, only the schooner Nautilus and the brig Syren were on blockade duty off Tripoli, ${ }^{55}$ but by the spring, Preble was able to station most of the squadron off Tripoli. When he arrived off Tripoli in the frigate Constitution in June, five U.S. warships were in

$51 N D B W, 3: 253-54$, William Bainbridge to Edward Preble, 5 Dec. 1803. Bainbridge wrote using similar language to Tobias Lear, the U.S. consul general at Algiers, observing that "[T]he coast [of Tripoli] is so situated as to make the most vigilant blockade prove inadequate [...] [T] he Island of Zirbe [Djerba] in the Regency of Tunis, adjacent to the boundary of Tripoli, would always be a port for the reception of goods destined to this place, - which could be readily conveyed in small boats along the shore, or brought on Camels, for a small expense; as these animals are numerous here, land carriage is exceedingly cheap." Ibid., 3:329-330, William Bainbridge to Tobias Lear, 14 Jan. 1804.

$52 N D B W, 3: 377-79$, Edward Preble to Tobias Lear, 31 Jan. 1804.

$53 N D B W, 3: 387$, Edward Preble to John Smith, 3 Feb. 1804.

$54 N D B W, 4: 57$, Edward Preble to John H. Dent, 24 April 1804.

$55 N D B W, 3: 437-38$, Edward Preble to James Leander Cathcart, 19 Feb. 1804. 
sight, and with the port "constantly kept closely blockaded," he hoped that the bashaw would "soon be sick of the War." 56

The blockade Preble began, which Captains Samuel Barron and John Rodgers maintained when they took command of the Mediterranean squadron, required "a roughand-ready knowledge of the laws of war rivaling the finest lawyers." ${ }^{57}$ The blockade resulted in approximately a dozen vessels intercepted, and sent into Malta or Syracuse for further inspection, before the bashaw agreed to peace with the United States in the summer of $1805 .^{58}$ The American captors decided to have U.S. courts pass on the validity of just two prizes: the cargo of a Maltese ship, and a ship seized from the Tripolitans, which Preble took into the squadron. ${ }^{59}$ Preble decided to restore most of the ships the squadron captured to their respective owners. With some captures, the restoration came immediately, because Preble recognized there was no legal basis for seizing a given vessel. $^{60}$ For others, Preble and the other commanders realized that even if a prize was technically lawful, embroiling the United States in diplomatic disputes with major countries was not wise. ${ }^{61}$ In dealing with the myriad problems presented by stopping

$56 N D B W, 4: 187-90$, Edward Preble to Robert Smith, 14 June 1804. The five cruisers were the Syren, Argus, Enterprize, Vixen, and Scourge.

57 John Fabian Witt, Lincoln's Code: The Laws of War in American History (New York, 2012), 86-87.

58 Despite the massive historiography on the Tripolitan War, there has been no analysis of whether (or to what extent) the blockade caused the bashaw to come to terms. Other factors that may have played induced the bashaw to come to terms were the overland attack by a force of mercenaries, Arabs, and U.S. marines, under Colonel William Eaton, which captured Derna, and threatened to undermine the regime, and the failure of the domestic grain harvest.

59 The cargo of the Maltese brig Santissimo Crocifisso was subject to legal proceedings in the U.S. District Court for Pennsylvania. The other case related to the merchant brig Transfer of 10 guns, which the Syren captured on 17 March 1804, departing from Tripoli. NDBW, 3:49596, Charles Stewart to Edward Preble, 17 March 1804. The Transfer had successfully run the blockade into Tripoli in mid-February, took on board a cargo of horses and olive oil, and then sailed for Malta, when she was captured. Ibid., 4:35, Diary of Edward Preble, 17 April 1804. Preble directed that the Transfer's papers be sent to America to condemn the ship, but Preble kept the brig, renamed Scourge, and added her to his blockading forces. Ibid., 4:4044, Edward Preble to Robert Smith, 19 April 1804. The Scourge served in the squadron for a year, and sailed to Norfolk upon the war's conclusion; the U.S. District Court of Virginia condemned the Transfer/Scourge on her papers.

60 For instance, in March 1804, six leagues north of Gozo, the northern island of the Maltese islands, the Syren stopped, and sent into Malta, a Prussian-flagged polacre, from Tunis and bound to Zante (in the Greek islands), carrying cannon and a "Number of Turks." NDBW, 3:471, Charles Stewart to Edward Preble, 4 March 1804. Preble "ordered the Prize Master and men to leave her immediately and gave her up to the Master to pursue his Voyage, as I conceived no just cause for detention." Ibid., 3:477, Edward Preble Diary Extract, 5 March 1804.

61 In June 1804, the Argus and Vixen stopped and seized a ketch called Le St. Jean Baptiste coming out of Tripoli in violation of the blockade, and sent her into Syracuse. NDBW, 4:149, Isaac Hull to George Dyson, 4 June 1804. Beaussier, the French consul at Tripoli, appealed to Preble, claiming that Tripolitan corsairs had made a prize of Le St. Jean Baptiste, which, 
ships of neutral nations, Preble showed prudence, an understanding of the law of nations, and a facility in dealing with legal problems. ${ }^{62}$ Preble's almost constant need to deal with the legal problems associated with the blockade and taking prizes also supports the thesis that naval officers in the early republic "needed to understand the rules governing the seizure of neutral and enemy shipping, not to mention the complexities arising when neutral ships held enemy goods." ${ }^{63}$ Although little studied today, the law of nations was a critical determinant of how American naval forces operated the war against Tripoli. Legal issues were never far removed from how the naval officers of the early American republic needed to approach their duties in creating and maintaining the blockade.

The author wishes to thank Christopher McKee, John D. Gordan, Esq., Tim McGrath, and Dr. Michael Crawford for reviewing an earlier draft of this essay, and for their advice and comments.

he asserted, was owned by French merchants in Marseilles, and she had been restored to the French owners only as a result of Beaussier's intercession with the bashaw. Ibid., 4:146, Beaussier to Edward Preble, 3 June 1804. Preble doubted Beaussier's word. Preble thought Beaussier was in league with the bashaw, and had contracted to furnish Tripoli with 500 barrels of gun powder. Ibid., 4:237-38, Edward Preble to Robert Livingston, 29 June 1804. Nevertheless, "in consequence of a demand from the [F]rench Government I ordered her immediate release.” Ibid., 4:187-90, Edward Preble to Robert Smith, 14 June 1804.

Although Preble had no doubt that the Maltese brig Santissimo Crocifisso was a good prize, caught violating the terms of Preble's own passport, he ultimately returned the vessel (but not her cargo) to the owners. Preble arranged a deal in which the owners: (1) bought the vessel back from him for $\$ 300$; (2) abandoned any interest in the cargo ("resigning up the Cargo," as Preble put it); and (3) provided "a full \& complete indemnification against all future claims or damages" against the captors or the United States. NDBW, 4:187-90, Edward Preble to Robert Smith, 14 June 1804. 